\title{
IDENTIFICAÇÃO DE PRAGAS E DOENÇAS EM SISTEMAS DE PRODUÇÃO EM TRANSIÇÃO AGROECOLÓGICA NA COMUNIDADE TANQUE SENZALA, EM SANTO AMARO, BAHIA
}

Gleidane de Freitas Souza ${ }^{1}$; Maria Zélia Alencar de Oliveira ${ }^{3}$ Felipe Oliveira Nunes² ${ }^{2}$ e Marina Siqueira Castro ${ }^{4}$

1. Bolsista PROBIC/UEFS, Graduanda em Agronomia/Membro do NEA-Trilhas (Núcleo de Estudos em Agroecologia), Universidade Estadual de Feira de Santana, e-mail: gleidane@live.com

2. Pesquisadora colaboradora do NEA-Trilhas e do Cetab/SEAGRI (Centro Tecnológico da Agropecuária da Bahia), Agrônoma pela Faculdade de Agronomia do Médio São Francisco - FAMESF e mestre em fitopatologia pela Universidade de Brasília (UnB)/, e-mail: zeliaao@gmail.com

3. Pesquisador colaborador do NEA-Trilhas, Biólogo e mestre em Ciências Ambientais pela Universidade Estadual de Feira de Santana, e-mail: nunesfo@gmail.com

4. Orientadora/Coordenadora do Centro de Agroecologia Rio Seco e do NEA-Trilhas, Departamento de Ciências Biológicas, Universidade Estadual de Feira de Santana, e-mail: marinacastro@uefs.br

PALAVRAS-CHAVE: Fitopatógenos; Diagnóstico; Manejo Fitossanitário

\section{INTRODUÇÃO}

O uso de agrotóxicos tem provocado a contaminação dos alimentos, do solo, da água e dos animais; a intoxicação de agricultores; a resistência de patógenos, de pragas e de plantas invasoras; o surgimento de doenças iatrogênicas; o desequilíbrio biológico com a supressão de organismos benéficos e a redução da biodiversidade (BETTIOL e MORANDI, 2009). Diante desses problemas, uma parcela dos agricultores vem buscando o uso de práticas agrícolas sustentáveis.

Porém, é imprescindível ter presente que a simples substituição de agroquímicos por adubos orgânicos mal manejados pode não ser solução, podendo inclusive vir a ser a causa de outro tipo de contaminação (CAPORAL, 2009).

$\mathrm{Na}$ agricultura orgânica, o manejo fitossanitário se baseia na prevenção, criando condições que desfavoreçam o surgimento de agentes de doenças e pragas nas plantas cultivadas. Contudo, quando a integração de práticas culturais impossíveis de evitar a ocorrência e contenção destes organismos em nível tolerável, são necessárias medidas emergenciais, tais como, uso de bioinseticidas e preparados caseiros (EMBRAPA, 2012).

Nesse contexto, torna-se importante o conhecimento dos problemas fitossanitários presentes em um sistema de produção, considerando este um dos fatores limitantes na produção agrícola.

Diante do exposto, foi realizado um levantamento fitossanitário para conhecimento dos agentes de doenças e insetos-praga associados aos sistemas de produção convencional (em transição agroecologia), visando a proposição de estratégias de manejo ecológico com reflexos positivos sobre o meio ambiente, na Comunidade Tanque Senzala, município de Santo Amaro, localizado próximo ao Centro de Agroecologia Rio Seco, uma vez que vêm se firmando no mercado como produtores orgânicos e passam por um processo de transição agroecológica.

\section{METODOLOGIA}

O levantamento foi realizado no período de janeiro a julho de 2017, na comunidade de Tanque de Senzala, município de Santo Amaro, na Bahia, que fica próxima ao Centro de Agroecologia Rio Seco que vem passando pelo processo de transição agroecológica. A escolha dessa comunidade se deu em consequência da forte demanda dos agricultores, haja vista os problemas de saúde, financeiros e ambientais causados pelo uso indiscriminado de agrotóxicos e fertilizantes químicos. 
Para conhecimento das práticas agrícolas adotadas pelos agricultores foram aplicados questionários semiestruturados, in loco, preenchidos pelo contato pessoal e levando em consideração a opinião espontânea dos entrevistados. Os questionários abordaram a descrição do agroecossistema e questões relativas às espécies cultivadas, aos insetos-praga e doenças.

A identificação das pragas e doenças foi determinada a partir de visitas as áreas de cultivo, observando os sintomas manifestados pelas plantas. $\mathrm{Na}$ impossibilidade da identificação imediata, foram coletadas amostras de partes vegetais, armazenadas em sacos de plástico e levadas para analise em laboratório.

As análises laboratoriais foram realizadas no Centro Tecnológico da Agropecuária da Bahia (Cetab), pertencente à Secretária de Agricultura do Estado da Bahia (SEAGRI), localizado em Salvador - BA. Para identificação da praga ou agente de doença, os materiais vegetais foram examinados, inicialmente, em microscópio estereoscópico. No caso de uma doença biótica, as amostras foram submetidas a uma avaliação preliminar para identificação da natureza do patógeno (fúngica, bacteriana ou virótica). Para a identificação de fungos, pelo método direto, as plantas foram examinadas ao microscópio estereoscópico e preparadas lâminas para observação das estruturas fúngicas ao microscópio ótico. Quando não foi possível a imediata identificação, fragmentos do material vegetal foram colocados em meio de batata-dextrose-ágar (BDA) para isolamento do agente patogênico (FERNANDEZ, 1993; ALFENAS e MAFIA 2007). Realizou-se a identificação dos organismos recuperados pela visualização de suas colônias e pela caracterização das estruturas ao microscópio óptico, com o auxílio da literatura especializada (BARNETT e HUNTER, 1998).

Os materiais com suspeita de infecção bacteriana passaram pelo teste de exsudação (ALFENAS e MAFIA 2007; LOPES e ROSSATO 2013).

Os insetos-praga foram identificados por meio de comparação com exemplares de coleções entomológicas e por consulta à literatura especializada.

\section{RESULTADOS E DISCUSSÃO}

Com relação à forma de produção e ao manejo dos cultivos agrícolas realizados pelos agricultores entrevistados, pode-se destacar que o foco da produção é de hortaliças e verduras e que o manejo adotado é o convencional, com uso excessivo de água, de adubos químicos e agrotóxicos e alta entrada de insumos externos.

No que diz respeito às fitodoenças, foram constatadas nas áreas visitadas de agricultores familiares, doenças de natureza biótica, incitadas por fungos, bactérias e algas e abióticas motivadas por deficiências nutricionais.

Em hortaliças foi detectado em alface (Lactuca sativa L.) o fungo Septoria lactucae Passerini e em cebolinha (Allium fistulosum L.) o patógeno ocasionador da mancha púrpura, Alternaria porri (Ellis) Cif. Estes agentes de doenças, sob condições ambientais favoráveis, podem reduzir a produção, ocasionando perdas econômicas. No tocante à couve-folha (Brassica oleracea L.) registrou-se a presença da bactéria Xanthomonas campestris pv. campestris (Pammel) Dowson agente da doença podridão negra das crucíferas. Este organismo sobrevive nas sementes, o que facilita a sua disseminação e introdução em áreas de cultivos livres da doença.

$\mathrm{Na}$ tabela 01 encontram-se registrados os patógenos associados, nas áreas visitadas, aos cultivos de hortaliças-fruto e tuberosa. 
Tabela 1. Problemas de natureza biótica constatados em hortaliças-fruto e tuberosa em áreas de agricultores familiares da Comunidade Tanque Senzala, em Santo Amaro, Bahia

\begin{tabular}{|c|c|c|c|}
\hline $\begin{array}{c}\text { Hortaliças } \\
\text { Fruto } \\
\end{array}$ & $\begin{array}{c}\text { Sintoma } \\
\text { Observado }\end{array}$ & Doença & $\begin{array}{l}\text { Patógeno } \\
\text { Detectado }\end{array}$ \\
\hline Milho & $\begin{array}{l}\text { Pústulas formadas em ambas as } \\
\text { superfícies das folhas, } \\
\text { apresentando formato circular a } \\
\text { alongado. }\end{array}$ & $\begin{array}{l}\text { Ferrugem } \\
\text { comum }\end{array}$ & $\begin{array}{c}\text { Puccinia sorghi } \\
\text { Schw. }\end{array}$ \\
\hline Quiabo & $\begin{array}{l}\text { Estruturas do fungo nas superfícies } \\
\text { superior e inferior das folhas, com } \\
\text { uma aparência semelhante a um pó } \\
\text { branco. }\end{array}$ & Oídio & $\begin{array}{l}\text { Erysiphe } \\
\text { cichoracearum De } \\
\text { Candolle }\end{array}$ \\
\hline $\begin{array}{l}\text { Hortaliça } \\
\text { Tuberosa }\end{array}$ & $\begin{array}{c}\text { Sintoma } \\
\text { Observado }\end{array}$ & Doença & $\begin{array}{l}\text { Patógeno } \\
\text { Detectado }\end{array}$ \\
\hline Beterraba & $\begin{array}{l}\text { Manchas de formato arredondado, } \\
\text { bordos de coloração púrpura e } \\
\text { centro claro. }\end{array}$ & $\begin{array}{l}\text { Mancha de } \\
\text { cercospora }\end{array}$ & $\begin{array}{c}\text { Cercospora beticola } \\
\text { Sacc. }\end{array}$ \\
\hline
\end{tabular}

Vale destacar que as doenças foliares causadas por fungos e bactérias acarretam necroses que reduzem a área foliar interferindo no processo fotossintético.

No que diz respeito às frutíferas o gênero Colletotrichum, ocasionador da antracnose, foi observado em aceroleira (Malpighia emarginata D. C.) e mangueira (Mangifera indica L.). Em bananeira (Musa sp.) constatou-se a doença sigatoka amarela, cujo patógeno é o fungo Mycosphaerella musicola Leach [Pseudocercospora musae (Zimn) Deighto.

No tocante às pragas observadas nos cultivos a maior incidência nas áreas visitadas foi de espécies-praga da Ordem Lepidoptera associadas aos cultivos de couve-folhas. A espécie de maior ocorrência foi a Curuquerê-da-couve - Ascia monuste orseis (Latreielle, 1819) Lepidoptera: Pieridae. Além dos danos registrados em couve-folha, esta praga foi observada em plantios de brócolis (Brassica oleracea L.), mostarda [Brassica juncea (L.) Coss.] e rúcula (Eruca sativa L.).

Ainda, pertencente à Ordem Lepidoptera foram constatadas a traça-das-crucíferas Plutella xylostella (Linnaeus, 1758) (Lepidoptera: Plutellidae), provocando danos a couvefolha, espinafre (Tetragonia expansa Murr. e feijão-mangalô - Lablab purpureus (L.) Sweet; Spodoptera cosmioides Walker, 1858 (Lepidoptera: Noctuidae), espécie extremamente polífaga, observada em hortelã-graúdo - Plectranthus amboinicus; e a lagarta rosca - Agrotis ipsilon (Hufnagel, 1766) Lepidoptera, Noctuidae em área com plantio de beterraba.

Outras pragas de importância econômica foram registradas: mosca-branca - Bemisia tabaci (Genn.) detectada em cultivos de couve-folha; Membracis sp. (Fabricius) - viuvinha ou soldadinho - Cigarrinhas / Membracidae em graviola (Annona muricata L.) e acerola; minador-das-folhas-dos-citros Phyllocnistis citrella Stainton (Lepidoptera: Gracillariidae) em citros (Citrus spp.); percevejos em plantas de pimenta e de jiló de capote.

Vale mencionar a ocorrência, em algumas áreas visitadas, de Artrópodes Predadores, tais como joaninhas (Coleoptera: Coccinellidae) e de aranha. Tal fato pode estar ligado ao manejo adotado pelo agricultor que, além de não utilizar agrotóxicos, põe em prática algumas ações como a consorciação de culturas na área de plantio. Outro ponto, também, que é oportuno enfatizar, diz respeito a convivência das culturas-chave com as plantas companheiras. 


\section{CONCLUSÃO}

Foram diagnosticados patógenos colonizadores da parte aérea, que podem debilitar a planta pela destruição da área foliar, interferindo no processo fotossintético, além de outros organismos, insetos-praga, cujos ataques podem levar a planta à morte. Tais constatações tornam claro haver necessidade de implementar medidas de controle, objetivando prevenir a ocorrência de epidemias com impactos ambientais e socioeconômicos.

\section{REFERÊNCIAS}

ALFENAS, A. C.; MAFIA, R. G. (eds.). Métodos em fitopatologia. Viçosa: Ed. UFV, 2007. 382 p., il.

BETTIOL e MORANDI, Biocontrole de doenças e plantas: uso e perspectivas. Jaguariuna, SP: Embrapa Meio Ambiente, 2009

CAPORAL, F. R. (Org.); PAULUS, G.; COSTABEBER, J. A. Agroecologia: uma ciência do campo da complexidade. Brasília, 2009. 111 p.

EMBRAPA. Manejo Fitossanitário em Cultivos Orgânicos. Embrapa Agrobiologia:

Seropédica, RJ, 2012.

LOPES, C. A.; REIS, A. Doenças do tomateiro cultivado em ambiente protegido. Brasília, DF: Embrapa Hortaliças, 2011. 17 p. (Embrapa Hortaliças. Circular técnica, 100).

LOPES, C. A.; ROSSATO, M. Diagnóstico de Ralstonia solanacearum em tomateiro. Brasília, DF: Embrapa Hortaliças, 2013. 10 p. (Embrapa Hortaliças. Comunicado Técnico, 92). 